\title{
War, Ethnicity, and Violence Against Women
}

\section{Jadranka Cacic-Kumpes}

Although seldom discussed in historical literature, rape is a disturbingly common part of the history of war. "Rape is more than a symptom of war or evidence of its violent excess. Rape in war is a familiar act with a familiar excuse." War rape is "a weapon of terror," "a weapon of revenge," and not uncommonly "the act of a conqueror" (Brownmiller 1991, 32, 35). Experts on rape theory claim that rape "is not for the most part the result of overwhelming sexual desire, but of the ties between sexuality and feelings of power and superiority... A substantial proportion of rapists in fact are only able to become sexually aroused once they have terrorized and degraded the victim. The sexual act itself is less significant than the debasement of the woman" (Giddens 1990, 184). It has also been shown that "in the context of a sexist and violent society, a low level of social integration and social control contributes to a high incidence of rape" (Baron and Murray 1989, 187). Since "rape is clearly related to the association of masculinity with power, dominance and toughness" (Giddens 1990, 184), one could say that war rape is a rough expression of the primitive power of patriarchal warriors over defeated victims. Or, to put it another way, it is a kind of war booty.

The data and statements I have collected from victims and witnesses of rape in Bosnia-Herzegovina ${ }^{1}$ reveal the exceptional cruelty of the rapists. Rape is directed not only toward women, but toward the ethnic group to which a particular woman belongs. Ethnic affiliation determines who will be victimized, while gender determines the kind of violence that will be perpetrated. It is important to note that statements made by men who were in (mostly) Serbian run "detention"

\footnotetext{
Jadranka Cacic-Kumpes is a researcher at the Institute for Migration and Nationalities at the University of Zagreb in Croatia.
}

camps in Bosnia-Herzegovina relay numerous accounts of sexual abuse and torture of men (i.e., forced sexual acts between male detainees, castration, etc.: see Amnesty International 1993; Globus, January 21, 1993).

In this paper I shall restrict myself to only one aspect of the suffering of civilians as a result of war: the suffering of raped women and girls, especially Muslim, since they are the majority of the afflicted population in the examined area. ${ }^{2}$ The large number of raped Muslim women, and the manner in which they were raped, suggest it is worth examining and correlating war tactics with instances of rape in Bosnia-Herzegovina. I shall also attempt to establish a correlation between the ethnic background of raped women and their position in a postwar period.

\section{The Sociocultural Context}

Data on rape have been collected for the Bosnian-Herzegovinian region, in particular Northern Bosnia and parts of western Bosnia and Highland Herzegovina. Bosnia-Herzegovina was considered one of the less developed republics of the former Yugoslavia. In 1981, 34 percent of the population were urban dwellers (as opposed to the Yugoslav average of 46.5 percent), and in the regions from which data were procured urban population was below the republican average. Illiteracy among those over ten years of age was 14.5 percent in Bosnia-Herzegovina, while the illiteracy rate of the total population of the former Yugoslavia was 9.5 percent. Illiteracy rates among Muslims in the former Yugoslavia averaged 17.5 percent, i.e. 6.9 percent among male Muslims, and as high as 28.1 percent among female Muslims. (Eighty-two percent of the nationally-declared Muslims in the former Yugoslavia lived in Bosnia-Herzegovina.) As of 1981, 18.4 percent of the population in Bosnia-
Herzegovina was Croatian, 39.5 percent Muslim, and 32 percent Serbian.

Although the position of women throughout the former Yugoslavia was more favourable than it had been before 1945 (in that year women received the right to vote for the first time), the patriarchal pattern of male domination has been slow to change. The main reason for this slow change should be located in the normative (e.g. family legislation and social policy) and the actual sphere (e.g. the economic system), which were discrepant in regard to female-specific issues as well as in regard to other general and particular problems. Regionally-differentiated levels of development in the former Yugoslavia along with diverse traditional cultures have also effected differences in the evolution of the patriarchal system (cf. Katunaric, 1984).

If we connect development indicators-such as small urban populations and high levels of illiteracy-with the specifics of cultural and historical development (a collision of three different traditions-Roman Catholicism, Eastern Orthodoxy, and Sunni Islam), it becomes obvious why changes in patriarchal patterns have progressed more slowly in Bosnia- Herzegovina than in the more developed and socio-historically more "homogeneous" areas of the former Yugoslavia, such as Slovenia. Some parts of Bosnia-Herzegovina were rapidly urbanized and industrialized after World War II, but patriarchy was nevertheless maintained through male cultural, economic, and social domination over women.

In Muslim families (and communities), this domination was especially pronounced. In Islamic society, men are valued for the way they take care of their families and, in the words of Mohammed, the good husband is "the one who is best to his wife" (Hamidullah 1982, 162). 
Bosnia-Herzegovina, especially in rural areas, has to a great degree preserved traditional values such as "honour," "face," virginity, and feminine chastity. The strength of the community and its men is reflected in the ability to preserve (and protect) the honour and integrity of families and women (see Denich 1974; Erlich 1978). This is the moral code (with all its internal contradictions) with which Muslim men are raised and which all sides in the present conflict understand very well.

Just as men have monopolized most of the institutions of power, so also "war has always been pre-eminently a male activity" (Giddens 1990, 352). Accordingly, women in the BosniaHerzegovinian milieu have in general been spared direct combat-caring for children has given them the "privilege" of not participating in armed conflicts. Instead, they have become refugees, while men have been deported back to Bosnia-Herzegovina in accordance with an interstate Croatian-Bosnia-Herzegovinian diplomatic agreement. Women who either could or would not flee shared their suffering with the remaining civilian population in the war zone, and many of them have become rape victims.

\section{Rape and War in Bosnia-Herzegovina}

Numerous sources have reported rapes committed by Serbian soldiers on women of Muslim nationality. As the war continues, it is not yet possible to completely verify the data, and control of the findings is possible only by comparing information from various sources and by checking the statements of victims and witnesses. ${ }^{3}$

There is no general agreement as to the number of victims. The report of the Coordinating Group of Women's Organizations of Bosnia-Herzegovina estimates that 20,000 to 50,000 women have been raped since the war started. On September 29, 1992, the daily paper Vecernji list (Zagreb) reported that the Serbian Orthodox metropolitan of Bosnia, Nikolaj, stated on an independent Belgrade television station that 30,000 Muslim women had be- come pregnant by rape. According to the EC Investigative mission, however, an estimated 20,000 Muslim women have been raped. (Cf. CacicKumpes 1992a, 4; 1992b, 98.) There is agreement in the above sources concerning several points: 1) the number of rapes has been massive; 2 ) the rape of young girls between seven and fourteen years of age has been massive; 3) rapes have been committed in the presence of parents/children of the raped persons; 4) generally, the victim is raped by several assailants.

Many witnesses have told of the brutality of the rapes. Men are separated from women and children. Young, educated, and affluent men are practically always killed, and women are then raped. Consecutive raping of girls younger than 15 years of age results in a high death rate or permanent physical damage. For instance, one woman from the village of Kozarac reported: "They take girls younger than thirteen to the camp, and then young women, and then take them to be raped several times." A man from Kozarac stated: "One day they led away five girls of thirteen years of age from M.'s house and the day after they returned them in such a state that the doctor S. P. barely managed to 'sew' two of them while the three others were sent to the Prijedor hospital, where they had been taken away to in the first place."

Daughters are often raped in the presence of their parents, mothers in the presence of their children, and wives in the presence of their husbands. A. L. from Brcko claimed: "That Ranko raped a woman-the mother of two children, and her mother was also present." According to one informant from Doboj: "H. R., Salih's son, hung himself after his wife Ramza had been violated by several Chetniks who raped her before his eyes." Another man from Kozarac gave this testimony: "Through the open window I heard the cries of women from a distance of about twenty metres away. One of them was crying as she said, 'People I was operated only a month ago!'. 'Do you have a mother?,' they asked, and brought before this girl her mother and father. They raped her mother before her father's eyes."

Women victims are led away from camps to trenches on the front lines for the satisfaction of the warriors. Serbian soldiers would threaten the women, saying they would go after their loved ones. More often than not, the women could save neither their relatives nor themselves. Some did not even want to remain alive. In the words of one woman from Miljevina: "They were all our neighbours. And they forced me from my house and took me to the house of that (neighbour) who had been shot and killed. There were four young girls there, young wives, and they led each one of them, one by one, into some room and there was nothing that they did not do to us. They beat us, abused us, raped us, they did anything they wanted. They threatened us that if we would say anything, they would come the next day and slaughter us and the children." A. L. from Brcko testified: "[T]hey raped the two daughters of R. H., who made use of an opportunity. He let the gas out and caused an explosion in which all were burned. R.H. was in the Bosnian Territorial Defense in the village of Rahic."

Furthermore, descriptions given by witnesses and rape victims, as well as the official reports, speak of the existence of a large number of "public houses" into which Muslim and Croat women are brought, of "special areas" in known concentration camps where Serbian soldiers sexually abuse women, and of "specialized" camps in which young girls and women are raped. Often those women who survive and become pregnant are held by Serbian soldiers in the camps until they are close to the end of their term, after which they are replaced by other victims or allowed to escape. According to a EC report, at present there is no proof that rapes were conducted on command, but all the descriptions and reports imply that there were no attempts to prevent them (and that they were perhaps encouraged). Statements have been made by rape victims that suggest the involvement of com- 
manding officers. For instance, one victimized Muslim woman states: "This same commander knew what was happening because he was one of them."

By comparing the ethnic picture of Bosnia-Herzegovina with the available data and locations of camps, i.e. information on rapes and "public houses," it is noticeable that massive rapes have occurred either in areas where Serbs are a minority, and Muslims are in relative or absolute majority (Brcko, Rogatica, Foca, Zvornik, Visegrad, Prijedor, Tuzla, Sarajevo, Bihac, Bosanska Krupa, Sanski Most), or in areas where Serbs are in a majority position but where there are significant Muslim and/or Croat minorities (Kalinovik, Kotor Varos, Banja Luka, Bijeljina, Nevesinje).

The cruelty of the rapists, and the extremely high incidence of rape, act as a sort of dialogue between male opponents. The woman as rape victim embodies the message that the more powerful opponent has conquered not only human "territory," but also has destroyed the symbolic expression of power of the defeated contestant, i.e. his honour. The aggressor destroys life meticulously, including material goods, cultural goods, and symbols. Thus the defeated party must also "disappear." Raped women are not only "sporadic" victims of violence, they are an integral and essential means of effecting genocide. Defeat of "the enemy" is embedded not only in rape itself, but also in fear of rape.

\section{Refugee and Post-refugee Periods}

The biggest problem for the arrested women is staying alive. The report of the Riyasat (September 28, 1992) stated: "During the liberation of Zuc from the Chetniks by the armed forces of Bosnia-Herzegovina naked girls and women were discovered, all of them massacred, some without heads. Even in the trenches the bodies of several massacred women and girls were found."

If they survive the camps and rapes and become refugees, new problems arise for the women. Family members are often killed, and husbands, if they are alive, are usually involved in the fighting. Alone and traumatized, these women and girls confront the daily refugee problems with internal turmoil: feelings of degradation and shame, as well as numerous prejudices derived from their patriarchal upbringing. For some refugee Muslim women, contact with a man other than her husband is seen as a sin (as is physical contact and possibly abortion). Many of them are not only disgusted by the prospect of possible future contact with men, they are also afraid that, even if desired, such contact would not be possible since their honour has been tarnished. As J.P. said: "Serb soldiers killed my entire family. Yes, I saw them as they killed my father, they cut his throat with a knife, then they shot my mother ... they took me to some room where about ten of them, consecutively, raped me for three days. It was terrible. I don't wish to remember it. I will never again be a normal woman" (Globus, September 25, 1992).

Experience shows that it is difficult to help women victims of war rape. They find it difficult to talk about rape, and are further traumatized by the reaction of their community. ${ }^{4}$ Despite attempts by society to negate stereotypes about rape (by emphasizing the high incidence of rape and the impossibility of victims to protect themselves), women feel stigmatized. Women's post-rape identity will affect not only their re-socialization, but also the children born as a result of the rape, the family, and the community itself. At the International Conference on Human Rights, representatives of Islamic countries urged pregnant raped women to give birth and raise their children in the spirit of Islam. They also advised Muslims to take such women as wives (Vecernji list, September 20, 1992). But it should be remembered that in Bangladesh, for example, "rape, abduction and forcible prostitution during the nine-month war proved to be only the first round of humiliation for the Bengali women. Prime Minister Mujibur Rahman's declaration that victims of rape were national heroines was the opening shot of an ill-starred campaign to reintegrate them into society - by smoothing the way for a return to their reluctant husbands or by finding bridegrooms for the unmarried ones ... Imaginative in concept, for a country in which female chastity and purdah isolation are cardinal principles, the 'marry them off' campaign never got off the ground" (Brownmiller 1991, 83).

The fate of these women and their children depends on the countries and communities where they find refuge (i.e. attitudes toward abortion, sensitivity to the preservation of the "Bosnian-Muslim" identity of the refugees, etc.), as well as on the refugee policies of the host countries (including the possibility of rape victims' selfhelp engagement through, for example, different women's groups). Above all, their fate is dependent upon circumstances related to the resolution of the war.

The desire to return home on the part of the refugees (mostly women and children, many of whom have lost loved ones and are homeless) will also depend on refugee policies and circumstances after the war. Since a great number of women have seen terrible crimes, and many have themselves been victimized, they will face the difficult issue of renewed coexistence in their home regions. The very crime continuously perpetrated against women and female children is sufficient that the remnants of the behumbled males (often themselves tortured and sexually abused), in as much as they survive the war as victors, spend the rest of their lives in revengeful activity (as noted by E. Fromm, the "thirst for revenge," which occurs after the damage has been committed, is of strong intensity, often cruel and insatiable).

In conclusion, one must remember that war limits accessibility to data that would make possible a thorough analysis of the correlation between ethnicity, war, and rape. The purpose of this study is to indicate the problems in question and to initiate further studies of this distressing phenomenon. 
Bourricaud, 670-79. Paris: Presses Universitaires de France.

1. In this paper, I attempt to explain the characteristics of rape (primarily) on the territory of Bosnia-Herzegovina after the breakup of socialist Yugoslavia. The paper is based on earlier investigations (CacicKumpes, 1992a and 1992b) as well as more recent sources.

2. The majority of sources (such as Amnesty Intem Internationl, ec in speak of rape cors (or paranititar foces) towad nonSerbian civilians, mosty Muslim wonn. Croatian women are also victims of Sebian aggession but are fewer number due to the demographics of the war-atflicted region. According to some sources (Amnesty International, newspapers), Serbia women were also raped by Muslim and Croatia armed forces "although on a much lesser scale" (Amnesty International 1993:6).

3. In this paper, I have used the following sources: information from the government of BosniaHerzegovina as presented in the mass media; specific reports (i.e. from the Direction for Humanitarian Aid of the Office of BosniaHerzegovina in Croatia, the Coordinating Group of Women's Organizations of the BosniaHerzegovinian government, the Riyasat of the Islamic Community, the EC Investigative mission into the tea tment of Muslin wom mission inc the the thent or Muslim women in the forme Yugoslania, 29 January 1993, Annesty Intenationl, 1993, statements withesses and rape victims in the archives of the Office or Bosnia-Herzegovina, the archives the Croatian Information Centre, the Departme for collecting documentation and processing data on the liberation war, collected statements Ibrahim Kajan's book Muslimallski danak 1 krvi; and reports and articles in the daily and weekly press.

4. In Vietnam, Laos, and Cambodia where chastity is held to be the highest virtue, there was" enormous cui tural pressure not to reveal rape Husbands have left their wives after learning the wife was raped"

(Boston Globe, June 8,1986)

References

Adorno, T. W., E. Frenkel-Brunswik, D. J. Levinson, and R. N. Stanford. 1950. The Authoritarian Personality. New York: Harper \& Row.

Amnesty International. January 1993. Rape alld Sexual Abuse by Armed Forces. Zagreb, Croatia. Baron, Larry, and Murray A. Straus. 1989. Four Theories of Rape in American Society. New
Hetrits. Theories of Rape in American Society. New Haven and London: Yale Univesily

Boston Globe. Boston: June 8,1986.
Boudon, Raymond, and Fran<;ois Bourricaud. Boudon, Raymond, and Fran<;ois Bourricaud.
1986. "Violence." In Dictionnaire critique de sociologie, edited by R. Boudon and F.
Brownmiller, Susan. 1991. Against Our Will. Men, Women and Rape. Harmondsworth: Penguin Books.

-. 1992a. "War, Ethnicity and Rape (The Case of Refugee Women from Bosnia)." Paper presented to the European (East-West) Conference on Women in a Europe in Transition: The Rights of Women in a Europe in Transition: The Rights of Immigrant and Refugens, Greece.

Cacic-Kumpes, Jadranka. 1992b. "Etnicnost, rat i silovanje." Migracijske 8, 2: 95-104. -.1993. "Education, Ethnicity and Con flict: The Case of Former Yugoslavia." The Joumal of Etlmo-Development 1, 3: 13-20.

Denich, Bette S. 1974. "Sex and Power in the Balkans." In Woman, Culture and Society, edited by M. Z. Rosaldo and 1. Lamphere, 24060. Stanford: Stanford University Press.

Erlich, Vera St. 1978. U drustvu s covjekom. Zagreb: SNL.

Fromm, Erich. 1976. The Anatomy of HUmall Destructil'eness. New York: Holt, Rinehart and Winston.

Giddens, Anthony. 1990. Sociology. Cam bridge: Polity Press

Globus. 1992. September 25. Zagreb.

Globus. 1993. January 21. Zagreb.

Hamidullah, Muhammed. 1982. Ul'od u Islam. Sarajevo: Starjesinstvo Islamske Zajednice Bosni i Hercegovini, Hrvatskoj i Sloveniji.

Kajan, Ibrahim. 1992. Muslimanski danak u krvi. Zagreb: Preporod.

Katunaric, Vjeran. 1984. Zellski eras i ci!'ilizaci;a smrti. Zagreb: Naprijed.

Kuper, Leo. 1981. "Theories of Genocide." Eth "ic llIId Racial Studies 4, 3: 320-33.

Porter, Roy. 1989. "Rape-Does it have a Historical Meaning?" In Rape: An Historical and Cultural Enquiry, edited by S. Tomaselli and R. Porter, 216-36. Oxford and New York: Basil Blackwell.

Rex, John, and David Mason, eds. 1988. TheoriesofRaceand Ethnic RelatiOlls. Cambridge: Cambridge University Press.

The Riyasat of Islamic Community. September 8 1992. Sarajevo.

Simmel, Georg. 1971. On Individuality and So cial FOYIIIs. Chicago and London: Univer sity of Chicago Press.

Smith, Huston. 1989. The Religions of Mall. New York: Harper \& Row. Vecemji list. September 201992. Zagreb. Vecemii list. September 291992. Zagreb. :J
Books receveived for review in Refuge

No More: The Battle Agains Human Rights Violations

$$
\text { by David Matas }
$$

ISBN 1-55002-221-0; 224 pp; \$19.99.

Published by: Dundurn Press Ltd., 2181 Queen St. E., Suite 301, Toronto ON M4E $1 \mathrm{E} 5$.

What leads to human rights violations and what can be done to stop them? What can be done to remedy them? The author attemts to answer these questions in No More.

David Matas practices law in Winnipeg specializing in refugee, immigration, and human rights, and is the author of Closing the Door: The Failure of Refugee Protection.

Constructing a Productive Other:

Discourse Theory and the

Convention Refugee Hearing by

Robert F. Barsky, Inter-University Celllre

for Discourse Analysis and Text

Sociocriticism, McGill University.

ISBN 1-55619-279-5; he, 274 pp; \$64.

Published by: John Benjamins Publishing Company, Amsteldijik 44, P. O.Box 75577, 1070 An Amsterdam, The

Netherlands.

Contents: Introduction: the construction of the Other; the chronotope for the Convention refugee hearing; interpreting and transcribing the Other; the discursive paradigm; life story; the un-dialogic Other; the explicit and implicit criteria for rendering the decision: the women as witness and the appeal case; and the destruction of the Self.

The Global Refugee Crisis:

A Reference Handbook by Gil Loescher

(Professor of IllIemational Relations. University of Notre Dame)

and Ann Dull Loescher (teacher) ISBN 0-87436-753-0; he, 261 pp; \$39.50.

Published by: ABC-CLIO, P. O. Box 1911,

Santa Barbara, CA, 93116-1911, US.A This book provides hard-to-locate facts, and statistics; Excerpts from major international and regional legal documents; directories of international organizations and US. resettlement agencies; selected print and non-print resources; and a glossary. 